\title{
第82回日本循環器学会学術集会
}

8. 冠動脈疾患のトランスレーショナルリサーチ

\section{冠動脈疾患疑い患者における VEGF-C レベルと死亡リスクの関連}

国立病院機構京都医療センター展開医療研究部和 田 啓 道

はじめに

血管内皮増殖因子 (VEGF) ファミリーとその 内皮特異的チロシンキナーゼ受容体は脈管形成, 血管新生, リンパ管新生の中心的な制御因子であ る ${ }^{1)}$. 哺乳類の VEGF ファミリーには VEGF（あ るいはVEGF-A とも呼ばれる), 胎盤由来増殖 因子 (PlGF), VEGF-B, VEGF-C, VEGF-D の
5 つが存在する (図 1). VEGF (-A) が VEGF 受 容体 2 (VEGFR-2) に結合することにより主要な 血管新生経路（VEGF シグナリング）が活性化さ れる.これに対して, VEGF 受容体 1 (VEGFR-1/ Flt-1) は, 発生の段階では, VEGFにより誘導 される血管新生に対して負の制御因子として働 く（デコイ［おとり］効果)。成体においては, VEGFR-1/Flt-1 は特異的リガンドである PlGF

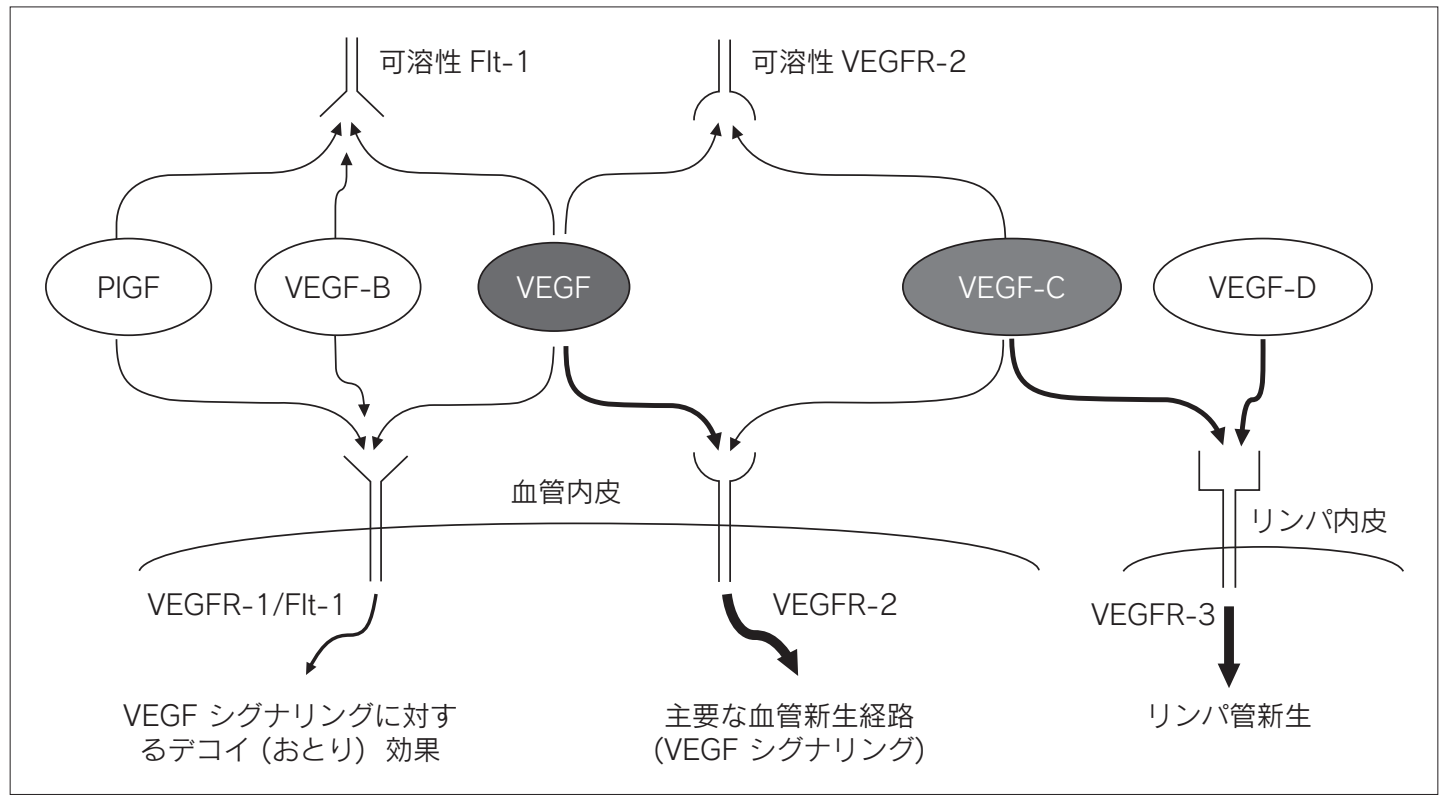

図 1 VEGF ファミリーと内皮特異的チロシンキナーゼ受容体

一脈管形成, 血管新生, リンパ管新生の中心的な制御因子-

[Keywords $]$ 冠動脈疾患, バイオマーカー, VEGF-C, コホート研究, 死亡 
とVEGF-B に活性化されると, 病的血管新生の 刺激因子として働くと考えられている.VEGFC と VEGF-D は, VEGF 受容体 3 (VEGFR-3) に結合してリンパ管新生を誘導する.

2 つのリンパ管新生因子の内，特に VEGF-C は生理的および病的リンパ管新生において中心的 役割を果たす ${ }^{2 \sim 5)}$. マウスの $V e g f c$ 遺伝子を欠失 させるとリンパ管が完全に消失して胎生致死とな る ${ }^{6)}$. 皮膚に VEGF-C を過剩発現させたトランス ジェニックマウスではリンパ管系の選択的過形成 が誘導される7)。これまでに報告された VEGF-C に関する臨床研究は, ほとんどが悪性腫瘍の診断 的可能性に焦点をあてたものであった. すなわ ち，腫瘍における VEGF-C の発現レベルや循環 血液中の VEGF-Cレベルがリンパ節転移, 遠隔 転移, および予後不良と相関していることが報告 されてきた ${ }^{8,9)}$.

最近の基礎研究の成果から, 心血管病における 新たな治療標的として, リンパ管系の重要性が注 目されている年10).リンパ管系はコレステロール 逆転送系（末梢組織から肝臓までコレステロール を移動して排泄する経路）やリポ蛋白の代謝，動 脈硬化形成に重要な役割を果たす ${ }^{5,10 \sim 13)}$. また, 心筋梗塞後に VEGF-C を投与すると, 心臓組織 にリンパ管新生が誘導され, 間質液のうつ滞が減 少し, 炎症細胞の排出が促進され, 心機能が改善 する ${ }^{14,15)}$.

われわれは, 明らかな疾患を有さない健診受診 者において, VEGF-Cレベルが（冠動脈疾患の 危険因子であり治療標的でもある）脂質異常と, 有意に関連することを報告した ${ }^{16)}$.しかしながら, 循環器疾患 (特に冠動脈疾患) における VEGFCレベルと将来の心血管イベントや死亡との関連 は不明であった。

\section{目的と方法}

われわれはVEGF-C と将来の心血管イベント および死亡のリスクとの関連を明らかにするため に, 国立病院機構 (NHO) 循環器グループ15施
設（北海道医療センター, 函館病院, 仙台医療セ ンター, 栃木医療センター, 埼玉病院, 横浜医療 センター, 相模原病院, 金沢医療センター, 京都 医療センター, 神戸医療センター, 岡山医療セン ター, 呉医療センター, 愛媛医療センター, 九州 医療センター, 熊本医療センター) による多施設 共同前向きコホート研究 (ANOX study) を実施 した ${ }^{17)}$. 対象患者は, 冠動脈疾患疑いのため, 待 機的に冠動脈造影を受ける患者とした。 経皮的冠 動脈形成術または冠動脈バイパス術後の予定され た再検査は除外した。 心臓カテーテル検査開始時 に動脈シースから血液を採取し, 市販の ELISA キットを用いて血清VEGF-Cレベルを測定した。

2010年 1 月から 2013 年11月の間に2,513例を登 録，同意撤回，対象外登録を除 $<2,418$ 例を 3 年間 追跡して，全死亡，心血管死亡，および，心血管 死亡と非致死性急性心筋梗塞と非致死性脳卒中の 複合エンドポイント (MACE) との関連を検討 した.

\section{結果}

登録後 3 年経過時点の追跡率は99.3\%であっ た。追跡期間中に全死亡254例，心血管死亡88例， MACE 165例が発生した。

登録時デー夕を VEGF-C の四分位に分けて検 討したところ，VEGF-Cレベルが低いほど，高 齢で，男性の割合が高く，やせており，低比重り ポ蛋白コレステロールや中性脂肪が低く, 慢性腎 臓病, 貧血, 心血管イベントの既往の割合が高 かった。すなわち, VEGF-Cの第一（最低）四 分位に属する患者は，ハイリスクで低栄養の傾向 があった。

年齢, 性別, 脂質異常, 高血圧, 糖尿病, 現在 喫煙，肥満，心血管イベント既往，慢性腎臓病 (CKD), 冠動脈疾患, 多枝または左主幹部病変, スタチン使用, アスピリン使用, 降圧剤使用によ る調整後に, VEGF-Cレベルは, 全死亡 (1 標準 偏差増加に対するハザード比 $[\mathrm{HR}], 0.69 ; \quad 95 \%$ 信頼区間 $[\mathrm{CI}], 0.60 \sim 0.80)$ ，心血管死亡 $(\mathrm{HR}$, 
0.67; 95\% CI， 0.53〜0.87）と有意な逆相関を認め た。しかしながら，MACEとは有意な関連を認 めなかった (HR, 0.85; 95\% CI, 0.72〜1.01).

心血管イベントとの関連が確立されている 3 つ のバイオマーカー, N-terminal pro-brain natriuretic peptide (NT-proBNP), 心筋トロポニン I, 高感度 $\mathrm{CRP}$ を上記の調整因子に追加したモ デルに, VEGF-Cレベルを追加すると, 全死亡 の診断能を有意に改善した。しかしながら，心血 管死亡と MACE の診断に関しては有意な改善を 認めなかった。

\section{考察}

本研究は, 冠動脈疾患疑い患者において, VEGF-Cレベルが全死亡と有意な逆相関を認め ることを, 最初に示した大規模前向きコホート 研究である，悪性腫瘍を有する患者において， VEGF-C 高值と予後不良との間に正の相関があ るとする, 従来の報告とは対照的な結果であり興 味深い. VEGF-C が悪性腫瘍の予後予測因子と して実用化に至っていない理由を示唆する結果と いえるかもしれない. NT-proBNP, 高感度トロ ポニン I, 高感度 CRP はいずれも高値のほうが 予後不良であるのに対して, VEGF-C は低值の ほうが予後不良であることから，VEGF-Cやリ ンパ管系は恒常性維持に重要な役割を果たしてい ることが示唆される。

本研究の登録時 (ベースライン) データにおい て, VEGF-C は CKD および貧血と逆相関を認め た。また, 既報と同様に, VEGF-C は肥満や脂 質異常とは正の相関を認めた ${ }^{16,18)}$ 。これらの相関 のもとにある機序について, 以下に考察する.

VEGF-C のソースがどこであるかはいまだ不 明であるが, 進行性腎線維化モデルである片側尿 管閉塞マウスにおいて，尿管閉塞により誘導され るリンパ管新生の, VEGF-C のソースのひとつ は近位尿細管であった ${ }^{19)}$. 近位尿細管は CKD 進 行と急性腎障害の主要なセンサーでありエフェク ターでもあるので20), VEGF-Cレベルの低下は,
少なくとも部分的には, 腎臟の近位尿細管障害を 反映している可能性がある.

マクロファージは, 腫瘍および炎症に誘導され るリンパ管新生の重要なメディエイターであり, 上記の進行性腎線維化モデルにおける VEGF-C のもうひとつのソースでもある ${ }^{19,21)}$. 興味深いこ とに, VEGF-C は, 古典的活性化 M1 (極性) マ クロファージよりも, 選択的活性化 M2 マクロ ファージにおいて発現レベルが高かった ${ }^{19)}$. し たがって, 腎線維化の過程で誘導されるマクロ ファージの形質変換が, マクロファージからの VEGF-C 分泌能に影響を与えているかもしれな い.

腎性貧血の主要な原因はエリスロポイエチンの 欠乏であるが, 乳がんとメラノーマのモデルマウ スにおいて, エリスロポイエチンはマクロファー ジにおける VEGF-C の発現を亢進して, リンパ 節転移と, リンパ節におけるリンパ管新生を誘導 する ${ }^{22)}$. 逆に VEGF-C は胎生期の赤血球造血に 必要不可欠であるが, 成体における赤血球造血 には大きな影響はない ${ }^{23)}$ 。したがって, 腎性貧血 のヒトにおいて, エリスロポイエチンはマクロ ファージからの VEGF-C 分泌制御に役割を担っ ている可能性がある.

VEGF-Cレベルは，肥満患者で上昇してお $り^{18)}$, 減量手術後に低下する ${ }^{24)}$ 。われわれは以前, VEGF-Cレベルが肥満そのものよりも, むしろ 脂質異常と密接に関連することを報告した ${ }^{16)}$. 注 目すべきことに, 最近の基礎研究の結果, 消化管 のリンパ管系が, 食事に含まれる脂質の吸収に重 要な役割を果たしていることが示唆された。すな わち, 成体マウスの VEGF-C を欠失させると, 皮膚や気管のリンパ管系には影響がないものの, 消化管のリンパ管が徐々に退縮することが判明し $た^{25)}$. 高脂肪食を負荷したマウスにおいて, 消化 管におけるリンパ管系の退縮は, 脂質の吸収を減 少させ, 粪便への脂質の排泄を増加させ, 肥満を 抑制し, 糖代謝を改善した。 もし, 血中 VEGFCレベルが, 消化管における（脂質吸収に必要な） リンパ管系の健全性を（少なくとも部分的に）反 
映しているとすれば，VEGF-C と脂質異常の正 の相関はよく説明がつく、いずれにせよ, VEGFC の血中レベルを規定する機序の解明には更なる 研究が必要である.

\section{本研究の限界}

第 1 に, VEGF-C 測定キットは研究専用であ り，臨床の現場での使用が承認されたものではな い. 第 2 に, 本研究は動脈血を用いており, より 広くリスクの予測に用いるためには静脈血による 検討が必要である. 第 3 に, 本研究は観察研究で あり，未測定の交絡因子が存在する可能性があ る。したがって, VEGF-Cが分子治療の標的と して役立つかどうかは不明である，この問いに答 えるためには, 将来的に介入研究が必要である. 最後に, ANOX study の対象者は冠動脈疾患疑 いのアジア人に限定されているので, 本研究の結 果をアジアの一般住人（健常者）や他の民族に一 般化することはできないかもしれない.

\section{おわりに}

冠動脈疾患疑いで待機的冠動脈造影を受けた患 者において, VEGF-C 低值は, 既知のリスクファ クター, NT-proBNP, 心筋トロポニン I , およ び高感度 CRP とは独立して, 全死亡と関連して いることが明らかとなった。

著者の COI (conflicts of interest) 開示: 本論文発表 内容に関連して特に申告なし

\section{文献}

1) Lohela M, Bry M, Tammela $T$ et al: VEGFs and receptors involved in angiogenesis versus lymphangiogenesis. Curr Opin Cell Biol 2009; 21: 154-165

2) Joukov V, Pajusola K, Kaipainen A et al: A novel vascular endothelial growth factor, VEGF-C, is a ligand for the Flt4 (VEGFR-3) and KDR (VEGFR-2) receptor tyrosine kinases. EMBO J 1996; 15: 290-298
3) Yang Y, Oliver G: Development of the mammalian lymphatic vasculature. J Clin Invest 2014; 124: 888897

4) Karaman S, Detmar M: Mechanisms of lymphatic metastasis. J Clin Invest 2014; 124: 922-928

5) Vuorio T, Tirronen A, Ylä-Herttuala S: Cardiac Lymphatics - A New Avenue for Therapeutics? Trends Endocrinol Metab 2017; 28: 285-296

6) Karkkainen MJ, Haiko P, Sainio K et al: Vascular endothelial growth factor $\mathrm{C}$ is required for sprouting of the first lymphatic vessels from embryonic veins. Nat Immunol 2004; 5: 74-80

7) Jeltsch M, Kaipainen A, Joukov V et al: Hyperplasia of lymphatic vessels in VEGF-C transgenic mice. Science 1997; 276: 1423-1425

8) Chen JC, Chang YW, Hong CC et al: The role of the VEGF-C/VEGFRs axis in tumor progression and therapy. Int J Mol Sci 2012; 14: 88-107

9) Wang CA, Tsai SJ: The non-canonical role of vascular endothelial growth factor-C axis in cancer progression. Exp Biol Med (Maywood) 2015; 240: 718724

10) Aspelund A, Robciuc MR, Karaman S et al: Lymphatic System in Cardiovascular Medicine. Circ Res 2016; 118: 515-530

11) Martel C, Li W, Fulp B et al: Lymphatic vasculature mediates macrophage reverse cholesterol transport in mice. J. Clin. Invest 2013; 123: 1571-1579

12) Lim HY, Thiam $\mathrm{CH}$, Yeo KP et al: Lymphatic vessels are essential for the removal of cholesterol from peripheral tissues by SR-BI-mediated transport of HDL. Cell. Metab 2013; 17: 671-684

13) Kutkut I, Meens MJ, McKee TA et al: Lymphatic vessels: an emerging actor in atherosclerotic plaque development. Eur J Clin Invest 2015; 45: 100-108

14) Henri O, Pouehe C, Houssari M et al: Selective Stimulation of Cardiac Lymphangiogenesis Reduces Myocardial Edema and Fibrosis Leading to Improved Cardiac Function Following Myocardial Infarction. Circulation 2016; 133: 1484-1497

15) Klotz L, Norman S, Vieira JM et al: Cardiac lymphatics are heterogeneous in origin and respond to injury. Nature 2015; 522: 62-67

16) Wada H, Ura S, Kitaoka S et al: Distinct characteristics of circulating vascular endothelial growth factorA and C levels in human subjects. PLoS ONE 2011; 6: e29351

17) Wada H, Suzuki M, Matsuda M et al: Vascular Endothelial Growth Factor-C Levels and Cardiovascular 
and All-cause Mortality in Patients With Suspected Coronary Artery Disease: From the ANOX Study. Circulation 2017; 136: A13751

18) Silha JV, Krsek M, Sucharda P et al: Angiogenic factors are elevated in overweight and obese individuals. Int J Obes (Lond) 2005; 29: 1308-1314

19) Lee AS, Lee JE, Jung YJ et al: Vascular endothelial growth factor-C and -D are involved in lymphangiogenesis in mouse unilateral ureteral obstruction. Kidney Int 2013; 83: 50-62

20) Chevalier RL: The proximal tubule is the primary target of injury and progression of kidney disease: role of the glomerulotubular junction. Am J Physiol Renal Physiol 2016; 311: F145-161

21) Ji RC: Macrophages are important mediators of either tumor- or inflammation-induced lymphangiogenesis.
Cell Mol Life Sci 2012; 69: 897-914

22) Lee AS, Kim DH, Lee JE et al: Erythropoietin induces lymph node lymphangiogenesis and lymph node tumor metastasis. Cancer Res 2011; 71: 4506-4517

23) Fang $S$, Nurmi $H$, Heinolainen $K$ et al: Critical requirement of VEGF-C in transition to fetal erythropoiesis. Blood 2016; 128: 710-720

24) Farey JE, Fisher OM, Levert-Mignon AJ et al: Decreased Levels of Circulating Cancer-Associated Protein Biomarkers Following Bariatric Surgery. Obes Surg 2017; 27: 578-585

25) Nurmi H, Saharinen P, Zarkada G et al: VEGF-C is required for intestinal lymphatic vessel maintenance and lipid absorption. EMBO Mol Med 2015; 7: 14181425 